\title{
The Argentine Archaeological Mission at Tell el-Ghaba. A Third Intermediate-Early Saite Period Site on the Ancient Egyptian Eastern Border. Remarks and Main Results
}

\author{
Silvia LUPO
}

\begin{abstract}
Twenty years after the Argentine Archaeological Mission first began its activities at Tell el-Ghaba, a Third Intermediate-Early Saite Period site located on the former eastern border of Egypt, now is the time to make some observations and to highlight the most significant results. This paper summarises the architectural features excavated so far and makes reference to the interactions of the site with other regions and the hypotheses about its destruction and abandonment.

Veinte años después que la Misión Arqueológica Argentina iniciara sus actividades en Tell el-Ghaba, un yacimiento del Tercer Periodo Intermedio y comienzos del Periodo Saíta localizado en la antigua frontera oriental de Egipto, resulta oportuno hacer algunas observaciones y destacar los principales resultados. Este trabajo resume los principales rasgos de las estructuras arquitectónicas excavadas hasta ahora y hace referencia a las interacciones del sitio con otras regiones, y presenta las hipótesis de su destrucción y abandono.
\end{abstract}

Keywords: Tell el-Ghaba, architecture, chronology, interactions

Palabras clave: Tell el-Ghaba, arquitectura, cronología, interacciones

Twenty

years after the Argentine Archaeological Mission first began its activities at Tell el-Ghaba, a site located on the ancient eastern border of Egypt, this is the chance to make some observations and highlight some of the most significant results.

Tell el-Ghaba lies in the northern coastal plain of the Sinai Peninsula, in what was once the Eastern Nile Delta, next to the Pelusiac branch of the Nile and on the route that linked Egypt with Palestine, the so-called Ways of Horus. The site is located between Tell Hebua to the west and Tell Qedua to the east, at the edge of the Eastern Lagoon. By the eleventh century AD a large influx of sediment carried by the Nile prevented water from reaching the Pelusiac branch, which silted up in 60 years (fig. 1) ${ }^{1}$.

In 1986 the Egyptian government designed the North Sinai Agricultural Development Project (NSADP), for which large scale agri-

\author{
TdE 7 (2016) - Páginas: 89-110 \\ Recepción: 10/10/2016 - Admisión: 25/10/2016 \\ Silvia Lupo - silvialupo@gmail.com \\ Consejo Nacional de Investigaciones Científicas y Técnicas / Universidad de Buenos Aires / Argentina
}




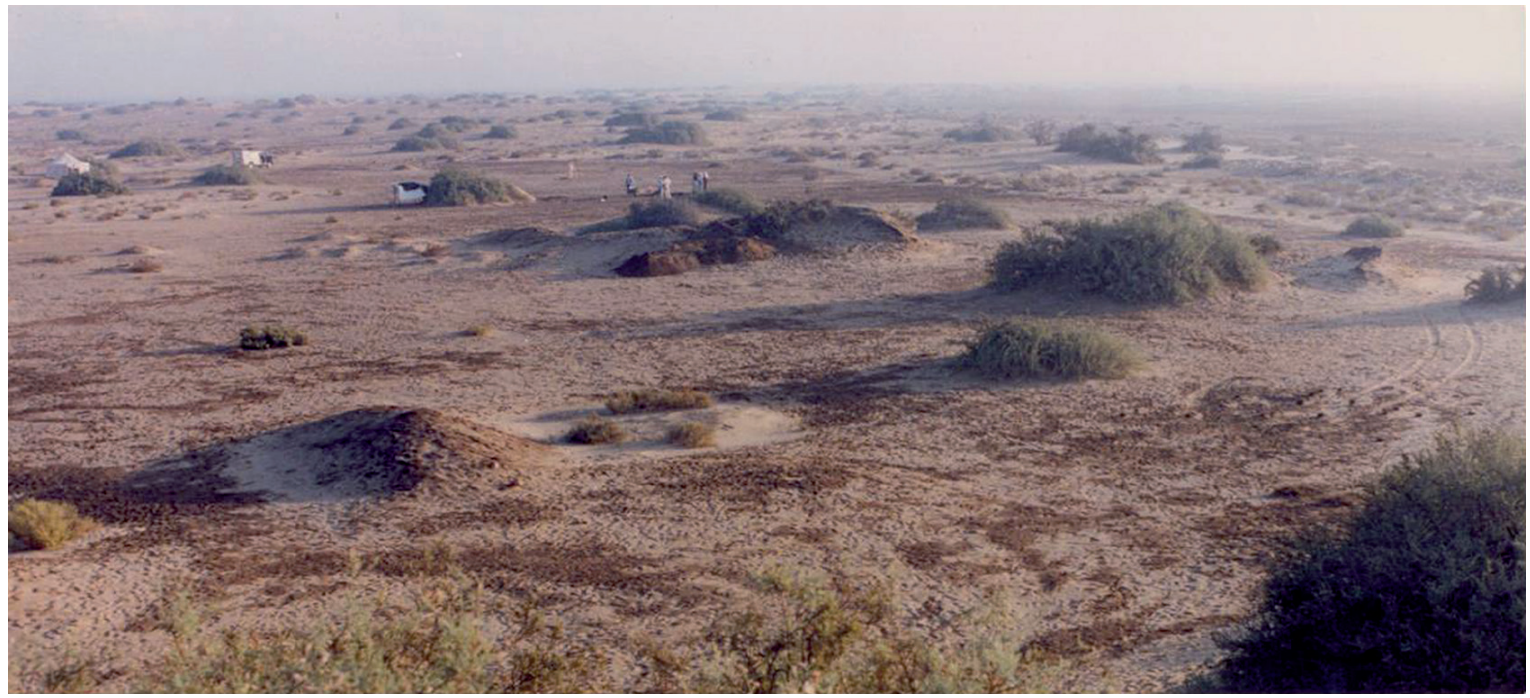

Figure 1. Tell el-Ghaba in 1995.

cultural works would be carried out to create fertile land and new inhabitable areas to solve demographic problems. The project encompassed the construction of a main canal running parallel to the Mediterranean from the Nile Delta to El-Arish (Peace Canal/ElSalam Canal), a network of secondary irrigation and drainage canals, new urban and rural settlements, and a new road layout that would later transform the typical deserted landscape of North Sinai. Accordingly, the Egyptian government, together with archaeological institutes of research headquartered in Cairo, generated an action plan for the study and preservation of the archaeological sites in North Sinai. In light of this, in 1992 the Archaeological Salvage Project of North
Sinai was created. This salvage project had the international cooperation of the Egyptian Supreme Council of Antiquities (SCA), the foreign archaeological missions working in the country and the UNESCO patronage ${ }^{2}$.

In 1990-1991, the French Mission at Tell el-Herr (directed by D. Valbelle) carried out a survey of Tell el-Ghaba for the $\mathrm{SCA}^{3}$. The results of this survey concluded that Tell el-Ghaba had been one of the most important settlements in the region and thus, an archaeological site to be protected ${ }^{4}$. As a result, the SCA commissioned the project to the Argentine Archaeological Mission. It was in the framework of this international salvage project that in 1995 Argentina started to work at Tell el-Ghaba5. When the Mis-

2 'Abd el-Maksoud, 1992: 7-12.

3 Valbelle, le Saout, Chartier-Raymond, 'Abd el-Samie, Traunecker, Wagner, Carrez-Maratray and Zignani, 1992: 11-22.

4 Valbelle, le Saout, Chartier-Raymond, 'Abd el-Samie, Traunecker, Wagner, Carrez-Maratray and Zignani, 1992: 18 .

5 This was the second time that Argentina had been engaged in a salvage project of ancient Egyptian monuments. In the 196os, Abraham Rosenvasser, co-director of the French-Argentine Mission in Serra West (Aksha), Sudan, together with Jean Vercoutter, participated of the UNESCO's appeal to safe- 


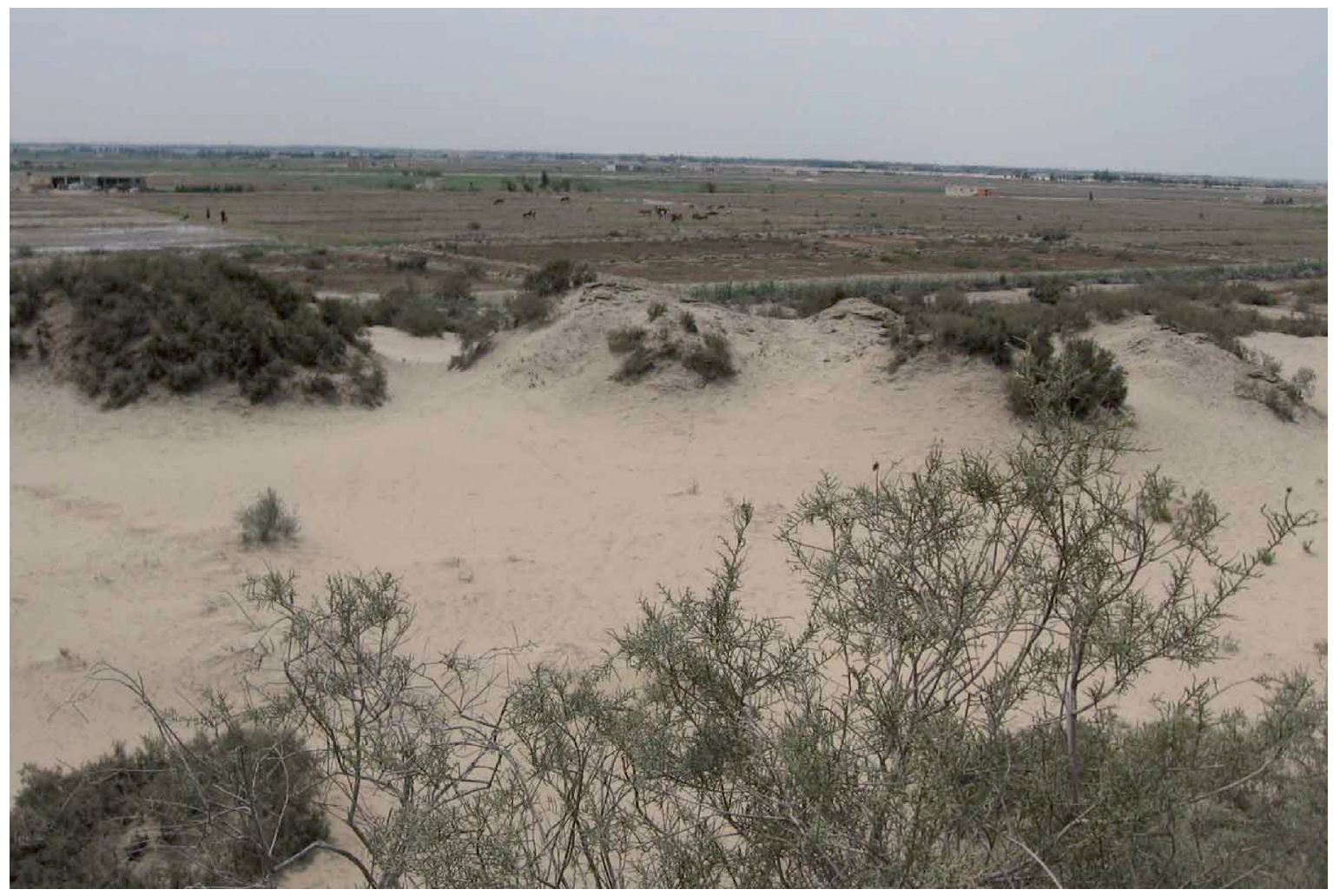

Figure 2. Tell el-Ghaba and its surroundings in 2010.

sion first arrived at the site, military vestiges of the Israeli occupation were still visible among the dunes. As for the vegetation of the site and its surroundings, it consisted mainly of tamarisks and other shrubs that Bedouins used as fuel.

During the years that the Mission worked at the site, we were able to witness the development of the North Sinai Agricultural Development Project. At present, the region is crisscrossed by several canals that have transformed the desert into farmland making it suitable for vegetable and fruit production, animal rearing and amateur fishing (fig. 2). The archaeological site has been preserved but, interestingly, the surrounding landscape has regained some of its old characteristic pattern of a river delta.

The general goal of the Argentine Archaeological Mission has been to contribute to the historical and archaeological knowledge of the region and, in particular, of Tell el-Ghaba. The project intends to conduct an integral research study of the material recovered from the excavations, reconstruct the environmental conditions and urban layout of the site, determine its chronology, learn about its economy and interpret both the

guard the monuments of Nubia before the construction of the Aswan dam. It is worth mentioning that Argentina is the only Latin American country with a long tradition of participation in archaeological salvage projects on the Nile. 
role of Tell el-Ghaba in the Egyptian border and its possible interactions with other sites in the Eastern Delta, North Sinai, the Levant and the Eastern Mediterranean from the middle of the tenth century BC to the late seventh century BC.

From 1995 to 1999, excavations in Areas I, II and VI were conducted by Eduardo Crivelli ${ }^{6}$. In 2010, fieldwork and lab activities were resumed with the aid of two grants from the National Bureau of Scientific and Technological Promotion of Argentina 7 . Under the field direction of Adriana Chauvin, excavations were undertaken in Area VIII ${ }^{8}$, adjacent to Area I, where a mudbrick structure (Building K) had been identified during a previous geophysical survey.

By the end of the 2010 season, a geomagnetic survey of the site was carried out by a team of the Polish Institute of Mediterranean Archaeology of the University of Warsaw, headed by Tomasz Herbich ${ }^{9}$. As a result of this survey, the site boundaries were determined and several buildings were detect$\mathrm{ed}^{10}$, though they have not been excavated yet due to the political events that affected Egypt in January 2011 (fig. 3). This survey also provided significant data on the settlement's urban layout.
The dating of the site has been one of the main concerns of the project. In a site with no meaningful epigraphic inscriptions, Egyptian pottery becomes an important chronological indicator ${ }^{11}$. As a complement, studies on imported pottery allow us to adjust the chronology of the site ${ }^{12}$.

Outlined below are the main results of the work carried out at Tell el-Ghaba in the last twenty years. These results have allowed us to identify the types of structures and urban development, establish the dating of the site, detect the interactions that Tell el-Ghaba may have had, and hypothesise about its destruction and abandonment.

\section{1 | Architectural structures}

The excavations of Areas I, II and VI of Tell el-Ghaba were carried out under the direction of Eduardo Crivelli Montero, who uncovered various architectural structures and established the typology of these buildings ${ }^{13}$. The following description is based on his studies ${ }^{14}$. In Area I, on top of the sterile sediment, there was a network of ditches, interpreted as the remains of fishermen's huts, which were abundant in hearths, fish remains and local domestic

6 Crivelli Montero, 2005; 2015: 63-94.

7 Préstamos BID/PICT $2007 \mathrm{~N}^{\circ} 1526$ and BID/PICT $2011 \mathrm{~N}^{\circ} 1883$, under the direction of Silvia Lupo.

8 Chauvin Grandela, 2010:183-200; 2015: 95-104.

9 Tell el-Ghaba geophysical survey, 2010: http://www.pcma.uw.edu.pl/en/pcma-newsletter/2010/.

10 Herbich, 2013: 121-130; 2015: 105-116.

11 Lupo, 2015: 139-305; Lupo and Kohen, 2015a: 327-340.

12 Kohen, 2015: 309-326.

13 This typology was presented at the XI International Congress of Egyptologists, August 23rd-3oth, 2015, Florence, Italy. Speakers: S. Lupo, E. Crivelli Montero and C. Kohen. Building B, a domestic construction at Tell el-Ghaba, North Sinai.

14 Mainly Crivelli Montero, 2015: 63-94. 


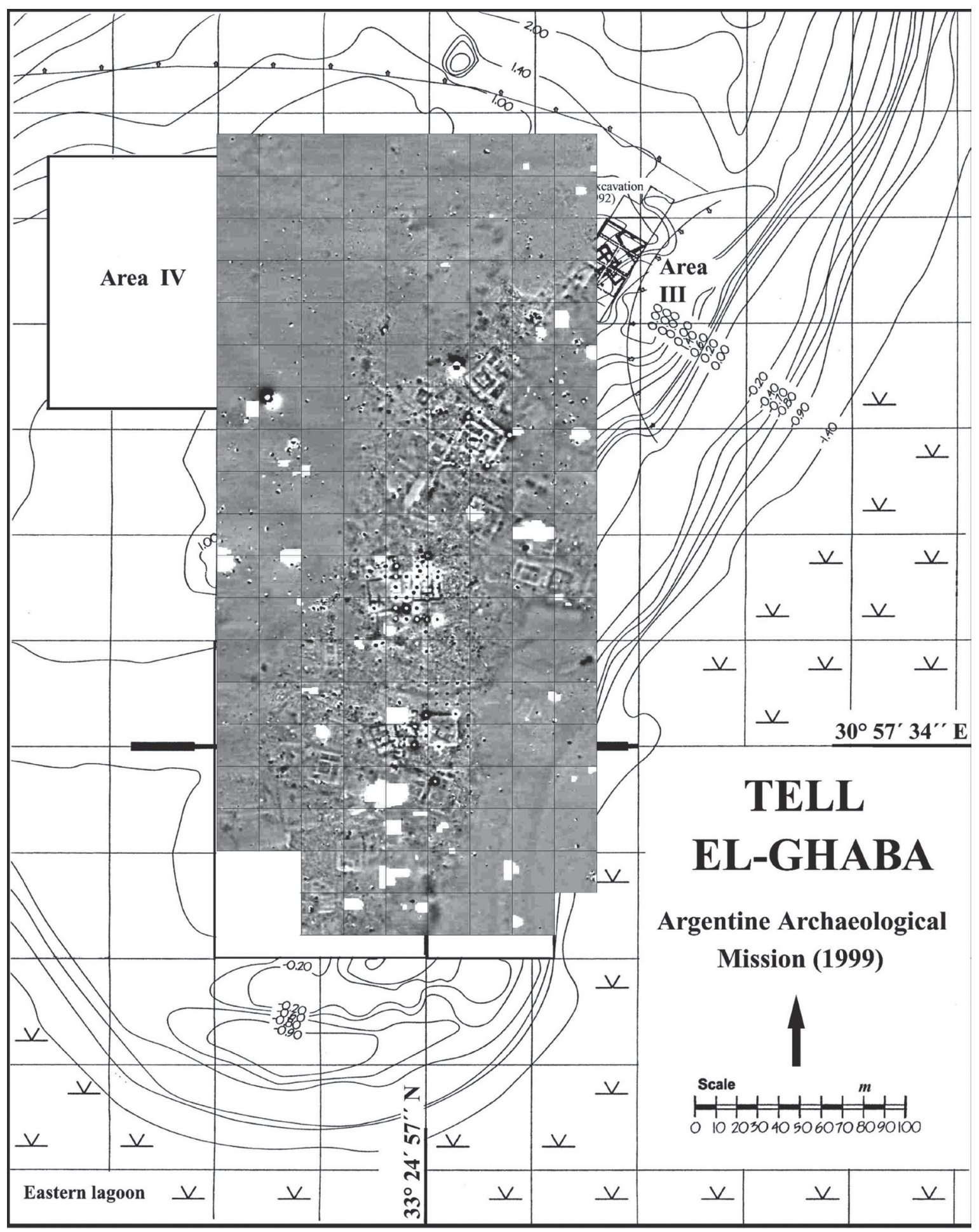

Figure 3. Geomagnetic survey at Tell el-Ghaba in 2010 (Tomasz Herbich). 


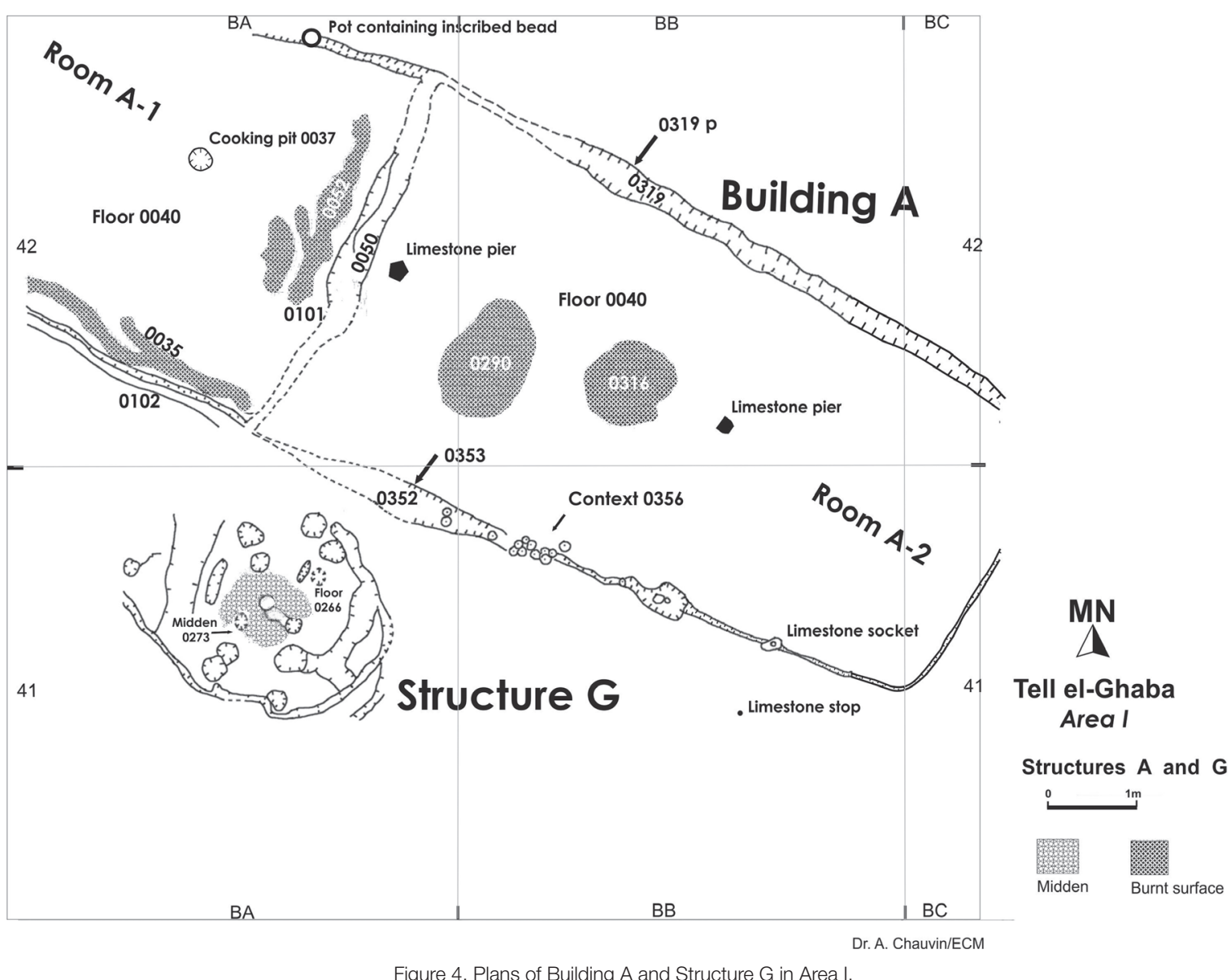

ware, including net weights and a hook ${ }^{15}$. The fill of these ditches was covered by sand (Lo266) which, in turn, was cut by two major features, a tent=Structure $\mathrm{G}$ and a reed hut=Building A (fig. 4), which signal the second occupational level of the site. These structures are considered archaeologically contemporary, since careful observation failed to note any stratigraphic difference between them ${ }^{16}$.
1. 1 Structure $G$ = tent

Structure $\mathrm{G}^{17}$ in Area I consisted of two roughly concentric, shallow ditches that demarcated a circular area about $2 \mathrm{~m}$ in diameter (fig. 5). The outer ditch was some $10 \mathrm{~cm}$ wide and the inner one, less clearly defined, was 20 to $35 \mathrm{~cm}$ wide ${ }^{18}$. Twelve circular or oval pits between 20 and $30 \mathrm{~cm}$ wide were found inside the feature, and

15 Crivelli Montero, Kohen and Lupo, 2012: 206; Crivelli Montero, 2015: 63.

16 Crivelli Montero, 2015: 64 .

17 Crivelli Montero, 2015: 69 .

18 Crivelli Montero, 2015: 69. 


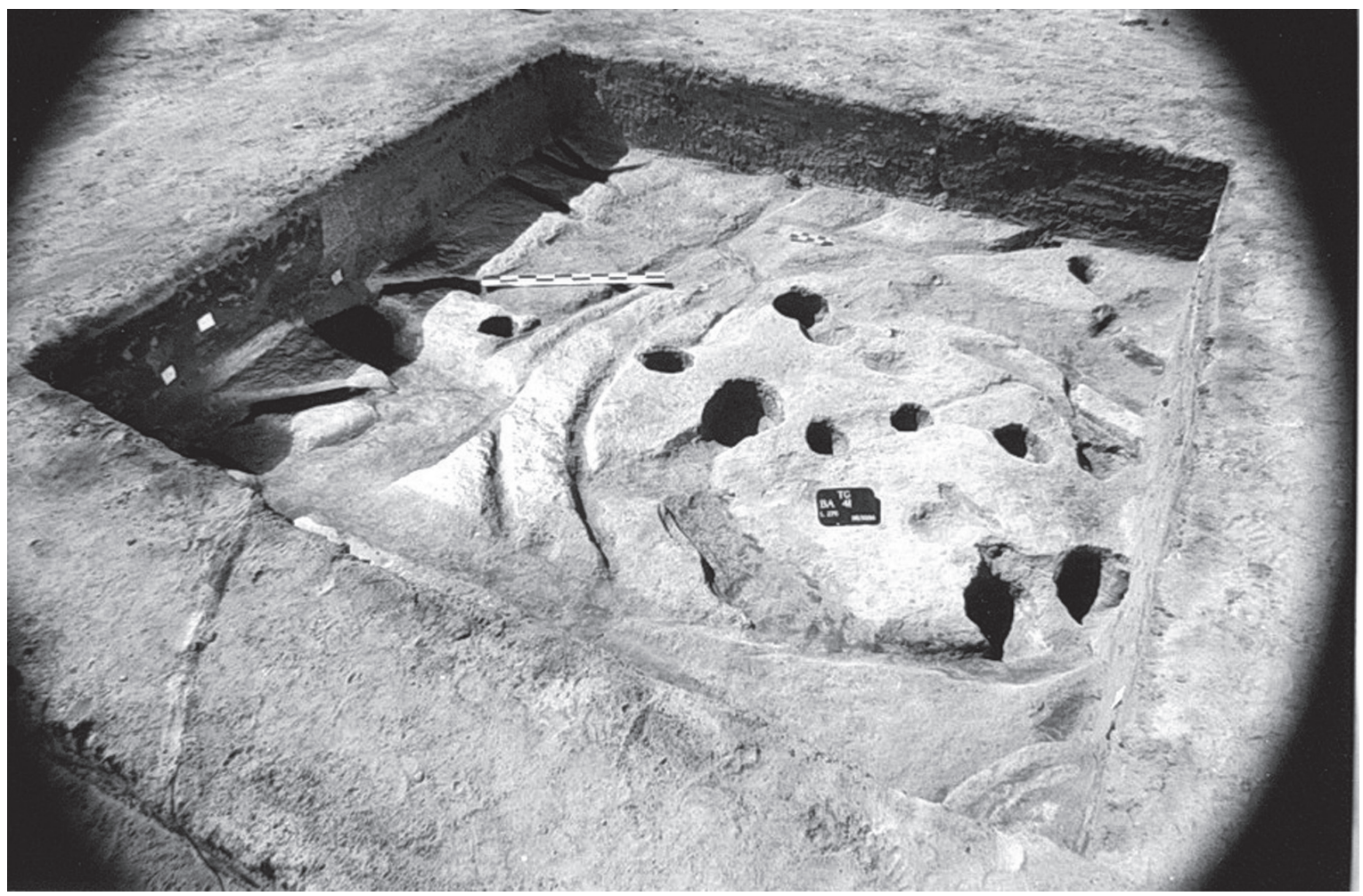

Figure 5. Structure G.

two more outside but very close to $i^{19}$. Since a pottery vessel was found inside one of the inner ones, Crivelli supposed that some of these pits might have been substitutes for furniture ${ }^{20}$. However, the rest of them were empty and they suggest the former position of posts, whichas valuable possessions-were retrieved when the light building was removed or abandoned $^{21}$.

In the centre of the circular area, a concentration, about $120 \mathrm{~cm}$ across, of bones and hearth charcoal, along with some pottery, several small finds and a net sink, was identified as floor Lo273 ${ }^{22}$.

The sub circular layout, the possible post holes and the short lived hearth (which had not oxidised the sand beneath) allow the excavators to interpret Structure G as a mobile shelter, perhaps a tent. The ditches and ridges in the sand Lo266 could have helped to sustain a piece of cloth or leather to protect from the sun and to prevent drafts ${ }^{23}$. Structure $\mathrm{G}$ seems to have been short lived and

19 Crivelli Montero, 2015: 69.

20 Crivelli Montero, 2015: 69 .

21 Crivelli Montero, 2015: 69.

22 Crivelli Montero, 2015: 69.

23 Crivelli Montero, 2015: 63. 
so, different in nature and perhaps in function from neighbouring Building A.

\section{2 | Building $A=$ reed hut}

Building A in Area I was a sub rectangular, axial structure of reed walls with at least two rooms. The longer axis of the construction runs WNW-ESE, the same as several other structures at Tell el-Ghaba. This consistency suggests an enduring regulation of the space $^{24}$.

Burnt marks identified in the northernmost foundation trench of Room A-2 suggest that the walls consisted of upright reeds or rush$\mathrm{es}^{25}$, a common building material employed until today by countrymen and Bedouins for short-term shelters ${ }^{26}$.
Building A was very close to Structure $\mathrm{G}$ and both were approximately but not strictly contemporary: the fire that thoroughly destroyed Building A did not affect Building $\mathrm{G}^{27}$.

The eastern room was roofed, as evidenced by two stone bases for poles, and featured two plain hearths. Room A-2 had an entrance at the south side, indicated by a door socket and the corresponding doorstop, both in limestone. Thus, the door was rather solid (of wood or bonded reeds) and swung open towards the outside (fig. 6) ${ }^{28}$.

In the northern and southern foundation trenches of this building, offering or votive objects were stored ${ }^{29}$.

In the southernmost trench of Room A-2 several objects, evenly spaced, were left when it was refilled (fig. 7): a sharpening

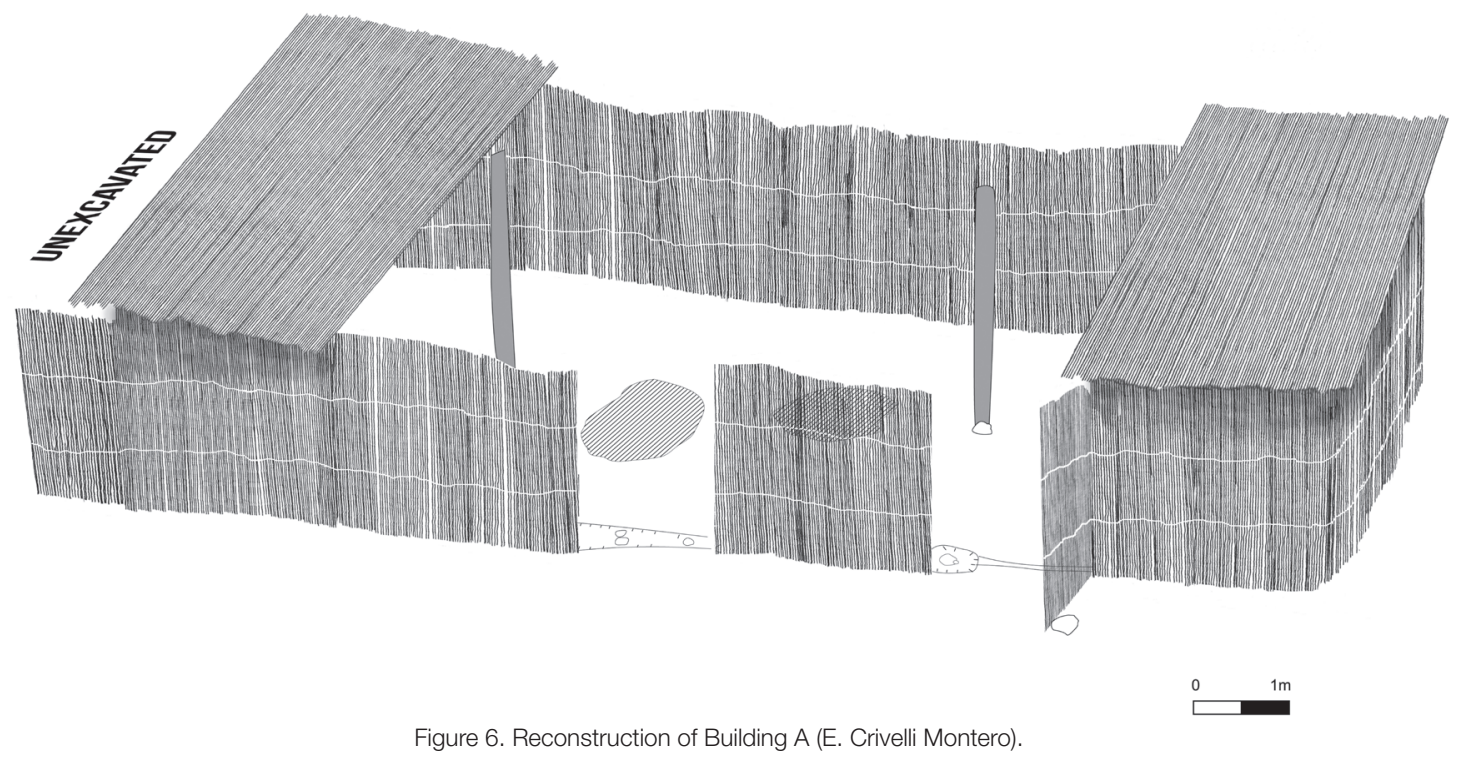

24 Crivelli Montero, 2015: 64. For the ceramic material, see Lupo and Kohen, 2015b: 199-235.

25 Crivelli Montero, 2015: 64 .

26 Crivelli Montero, 2015: 64 .

27 Crivelli Montero, 2015: 64 .

28 Crivelli Montero, 2015: 64. Designed by Eva Calomino.

29 Crivelli Montero, Kohen and Lupo, 2012: 205-219; Crivelli Montero, 2015: 64 . 
stone, a dipper juglet, a bottle manufactured in Marl $\mathrm{F}^{3}$, slag, a fragment of a bronze object, a faience bead and a hoard of seventeen doughnut-shaped objects of baked and unbaked clay (likely loom weights) made of Nile clay that were identical to those found in Palestine and Levantine sites dated to the Iron Age II ${ }^{31}$.

Resting on the fill of the northern foundation trench (Room A-1) ${ }^{32}$, where the burning was not so intense, the above mentioned bi- chrome jar33 (fig. 8) was found containing a plaque with hieroglyphic inscriptions carved on both faces (fig. 9). The plaque preserves the cryptographic writing of Amun, which reads: "Amun (is) the Lord of Eternity" (literally, "It is Amun the Lord of Eternity") 34 .

In Area II, a narrow ditch (some $20 \mathrm{~cm}$ wide) was filled with oxidised and carbonised sediment, which contained an assortment of sherds and three clay doughnut-shaped loom weights or stoppers for fermentation

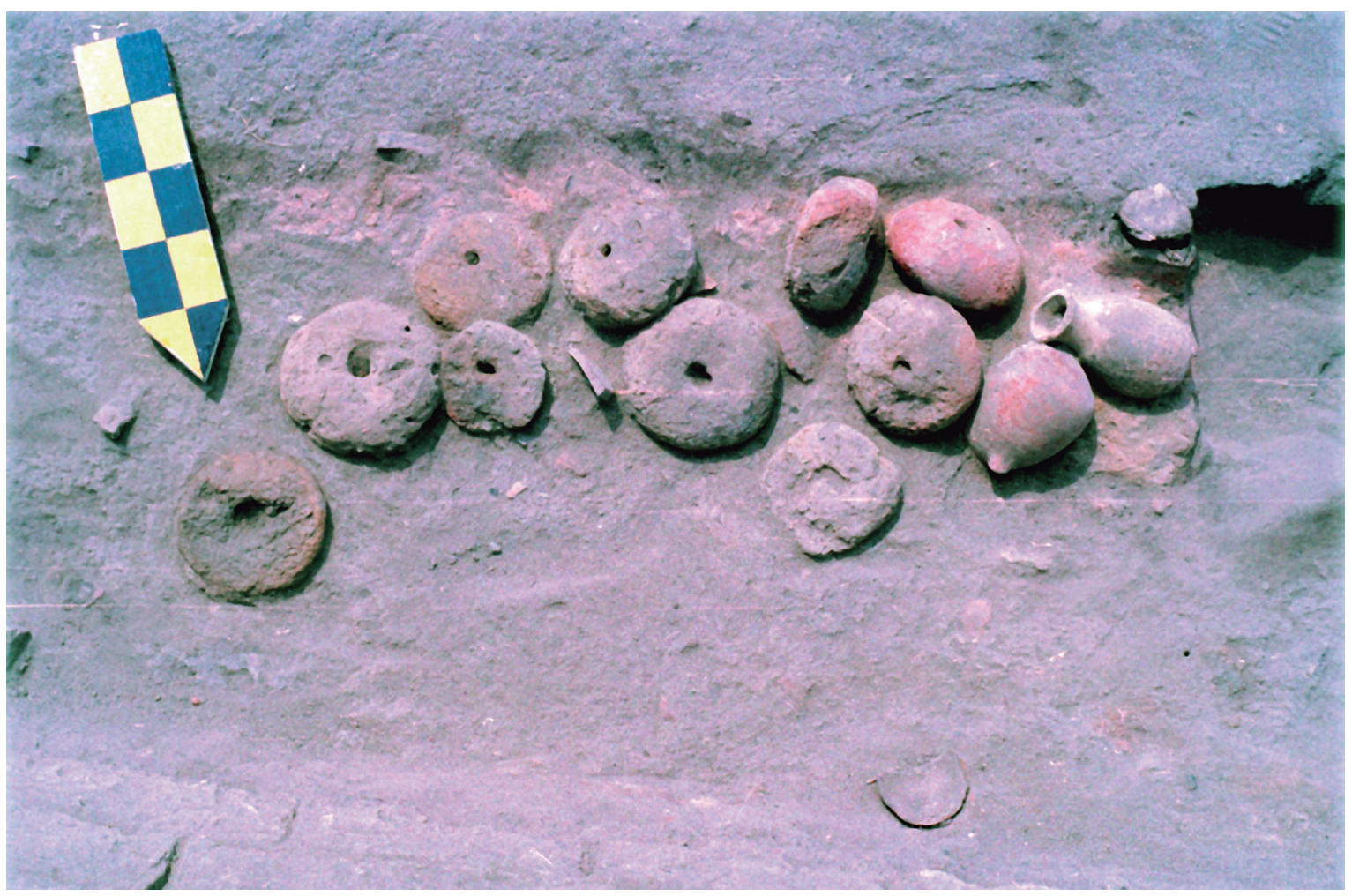

Figure 7. Southern foundation trench, Building A.

30 Reg. No. 1092 (Lupo and Cremonte, 2013: 212, fig. 4); Crivelli Montero, Kohen and Lupo, 2012: 210, fig. 7). For the contents of foundation deposits, see Weinstein, 1973 and Marchand, 2004.

31 Crivelli Montero, Kohen and Lupo, 2012: 205-219.

32 Crivelli Montero, Kohen and Lupo, 2012: 205-219; Crivelli Montero, 2015: 64 .

33 Crivelli Montero, Kohen and Lupo, 2012: 215-216.

34 Crivelli Montero, Kohen and Lupo, 2012: fig. 5, 216-218. 


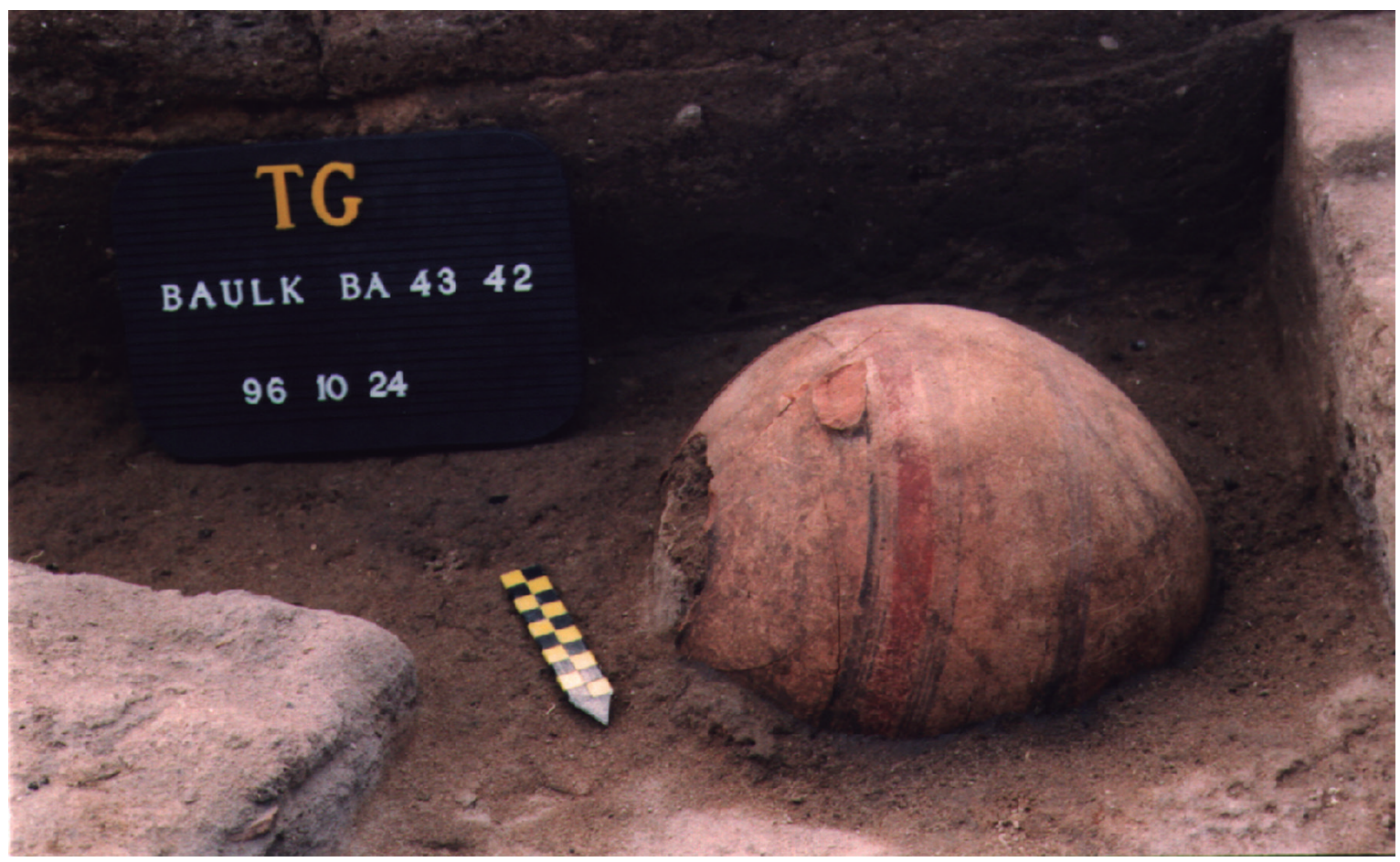

Figure 8. Northern foundation trench. Building A, bichrome jar in situ.

(fig. 10). This calls to mind the south foundation trench of Building A, where similar objects were found embedded in its burnt fill. This feature was conjecturally labelled Building M ${ }^{35}$.

On the basis of the material found in both structures, the foundation deposits of Building A and Building $\mathrm{M}$ seem to be the oldest architectural features found so far at the site.

\section{3 | Mudbrick Buildings}

Several rectangular mudbrick buildings of different layout were uncovered at Tell el-Ghaba.

\section{Building B}

After the burning of Building A in Area I, this part of the site remained unoccupied for some time, as indicated by the accumulation of dark, carbonaceous and featureless fill, Lo289, a thinly layered unity resulting from the washing out of remains of former occupations ${ }^{3}$. The walls of Building B were erected directly on this locus, without foundation trenches.

Building B (fig. 11) is a mudbrick structure, rectangular in layout, measuring about $13 \mathrm{x}$ $9 \mathrm{~m}$, with the main axis oriented ESE-WNW. It comprises eight rooms, one of them a small magazine.

When found, the walls of Building B were only one to four courses high, that is, about

35 Crivelli Montero, 2015: 76.

36 Crivelli Montero, 2015: 69-74. 
The Argentine Archaeological Mission at Tell el-Ghaba. A Third Intermediate-Early Saite Period Site... Silvia Lupo
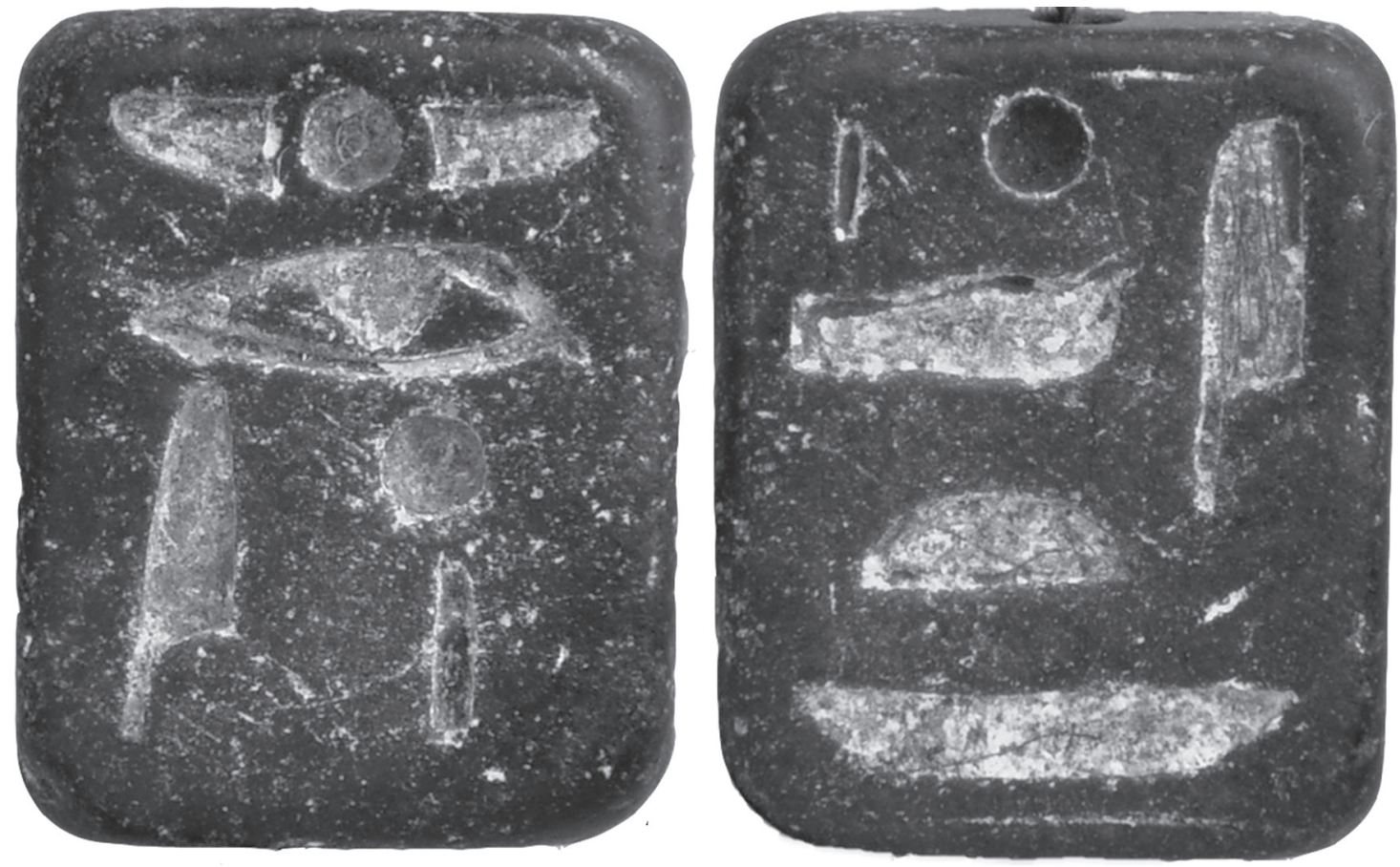

Figure 9. Building A, northern foundation trench. Plaquette found inside the bichrome jar.

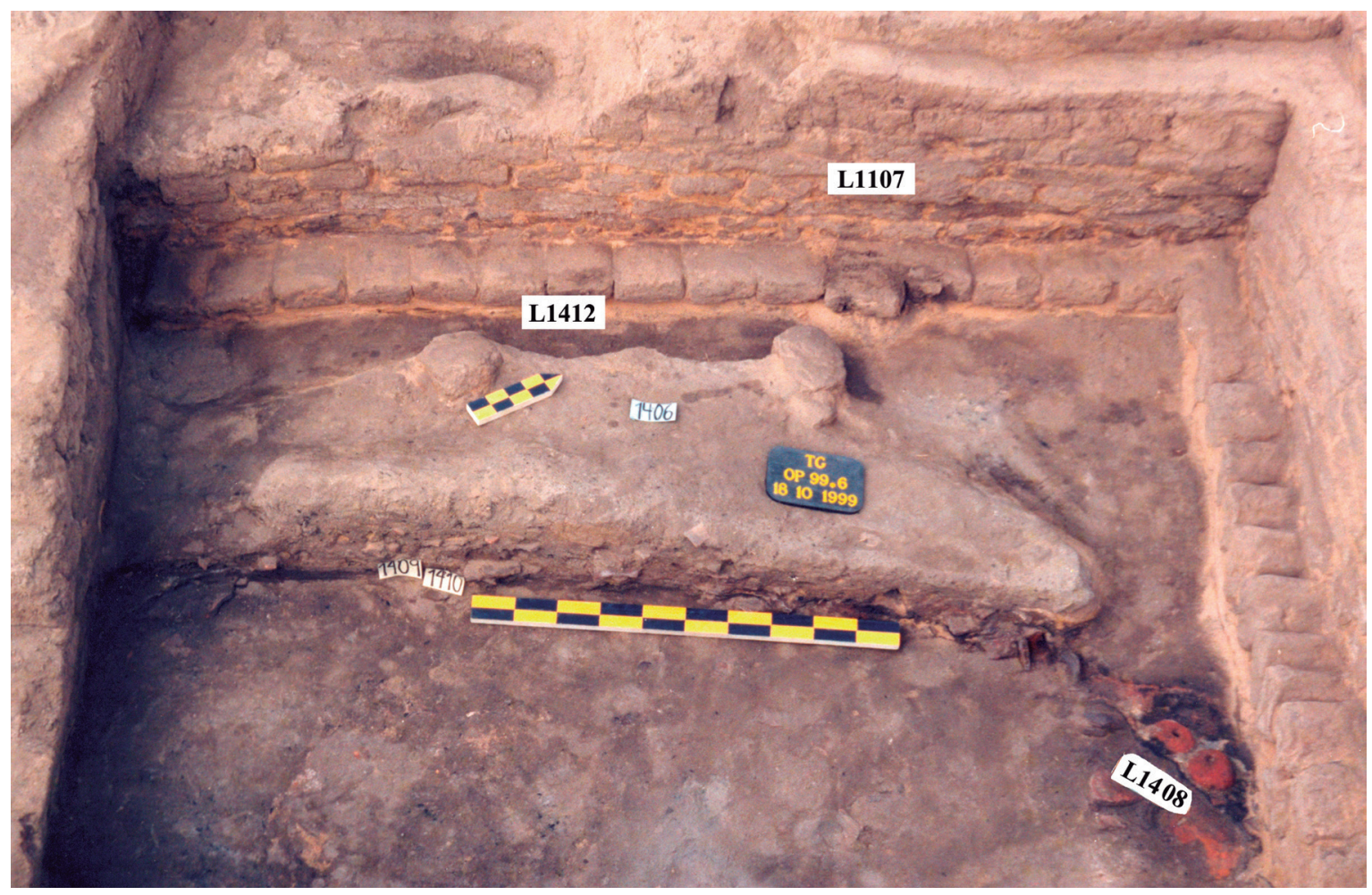

Figure 10. Foundation trench of Building M. 


\section{Area I}

\section{BUILDING B}

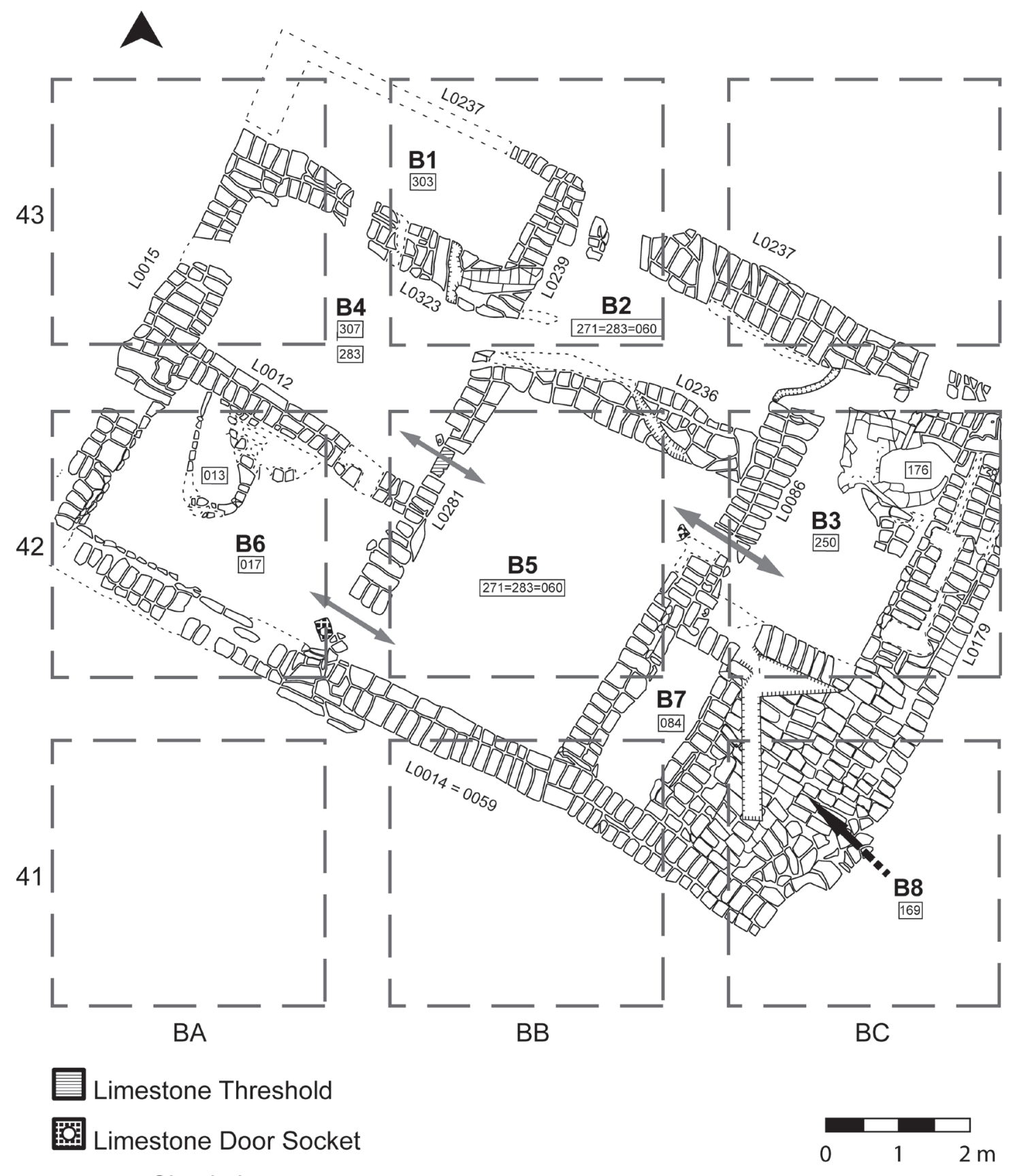

Figure 11. Plan of Building B. 
$23-25 \mathrm{~cm}$ high on average. Only the external wall (Lo179) preserved five courses and was 40-50cm high.

Openings, door sockets and a threshold give an idea of circulation inside Building B. Room B-5 was the largest and could be accessed from rooms B-3, B-4 and B-6. Perhaps it was also from B- 5 that magazine $\mathrm{B}-7$ could be reached. B-7 was small and full of pottery containers, which may have been handled from the top. In this case, a door trap could have closed the magazine. The spaces B-1 and B-8 were seriously damaged by later cuts and their links with the rest of the building are not clear. B-1 seems to have been accessed only from Room $\mathrm{B}_{4}$. The exterior may have been gained across Room B-8, a space paved with mudbricks.

There are indications that Building B was refurbished as suggested by: 1) the presence of a hearth that was intercalated among the mudbricks of the western external wall (Loo23) when part of the wall collapsed and before its reconstruction; 2) the different composition and size of the upper mudbricks in the same wall and in the internal wall (Lo281); 3) and the renewed floors, as in the case of Room B-4, where a superposition of floors was noted 37 .

The presence of the aforementioned magazine and the two ovens suggest that Building $B$ may have been the residence of an extended family ${ }^{3}{ }^{8}$, perhaps for several generations as denoted by the refurbishment of the building. High economic status can be inferred from the presence of a gold bead in Room B-6, a few Upper Egyptian vessels and small fine Cypriote Black-on-Red ridgeneck juglets.

Building L

Building $\mathrm{L}$ is a multi-roomed mudbrick structure that went through several phases of utilisation (fig. 12) ${ }^{39}$. One of its rooms was a magazine in which storage jars were $\operatorname{kept}^{4^{\circ}}$.

\section{Building $\mathrm{F}$}

Between areas I and II, Building F in Area VI was built in mudbricks without foundation trenches (fig. 13). Its orientation is NNW-SSE and it was excavated only partially. This building was severely deflated: only two to six courses of mudbricks are left and the floors have been swept away. In the excavated part, the walls delimit sixteen rectangular spaces of very different size.

One of its sides measures around $25 \mathrm{~m}$ while the other is not less than 20m. In the exposed area there are seventeen rooms with a size range that varies from 5 to $20 \mathrm{~m}^{2}$. According to Herbich's survey, Building F measures $35 \times 20 \mathrm{~m}^{41}$.

\section{4 | Tower houses}

Two massive mudbrick structures were exposed in Area II: Building C (in Area

37 Crivelli Montero, 2015: 74.

38 Lupo, Crivelli Montero, Kohen, Building B, a domestic construction at Tell el-Ghaba, North Sinai, in XI International Congress of Egyptologists, Florence, August 2015.

39 Crivelli Montero, 2015: 76-79.

40 Crivelli Montero, 2015: 76-79.

41 Herbich, 2015: 105-116. 


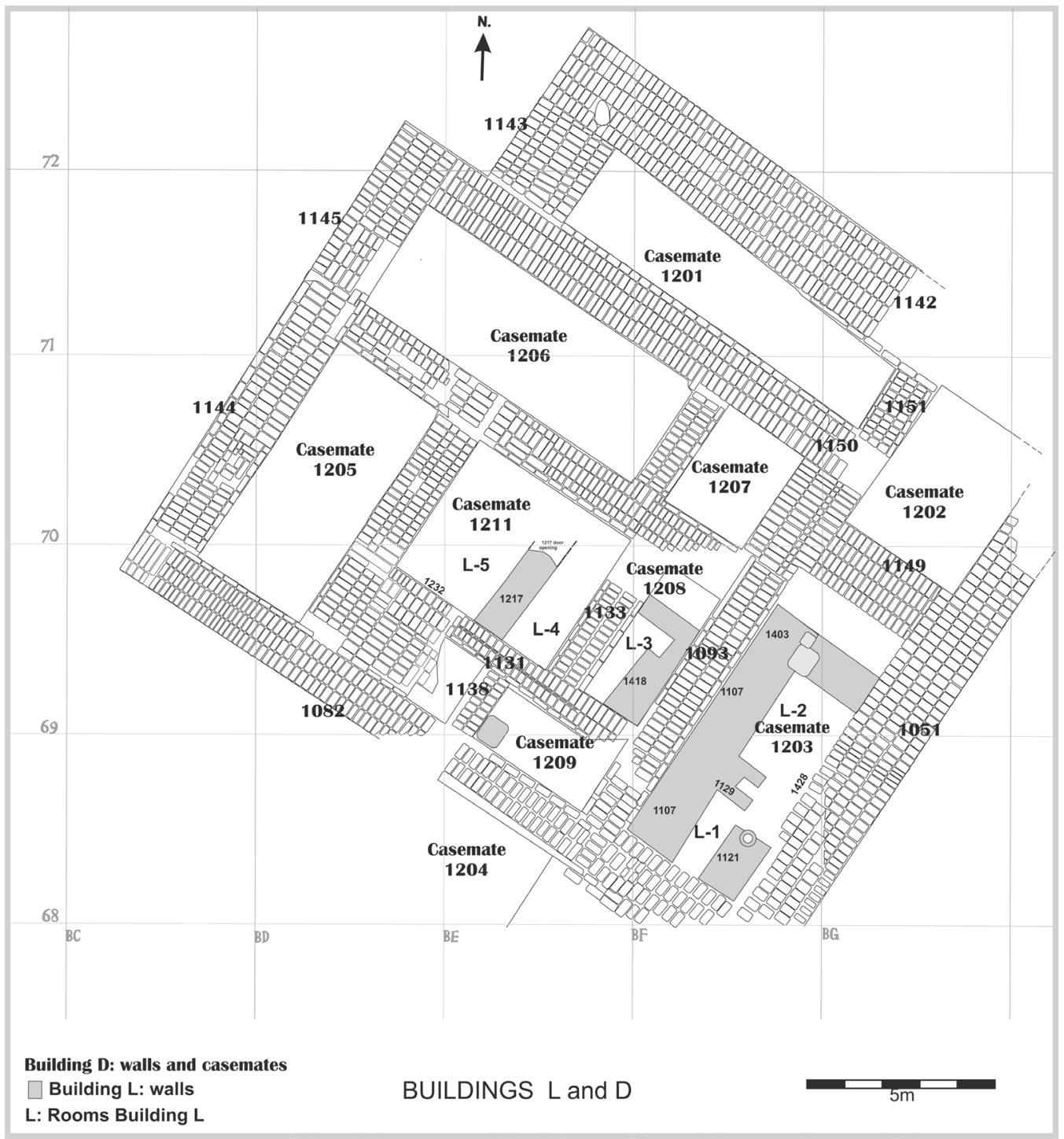

Figure 12. Building $L$ beneath Building $D$.

II West) and Building D (in Area II East). Both buildings feature thick walls, appropriate to support the burden of upper floors. Unfortunately, only the foundations or substructures have remained; neither doorways nor door sockets were found ${ }^{42}$.
Building D

Mudbrick Building D was built overlying Building L and was oriented NE-SW (fig. 14). It forms an irregular rectangle of around 20 to $22 \mathrm{~m}$, with a sort of niche or recess in the NW. Exterior walls (or their respective

42 Crivelli Montero, 2015: 82-89. 
The Argentine Archaeological Mission at Tell el-Ghaba. A Third Intermediate-Early Saite Period Site... Silvia Lupo

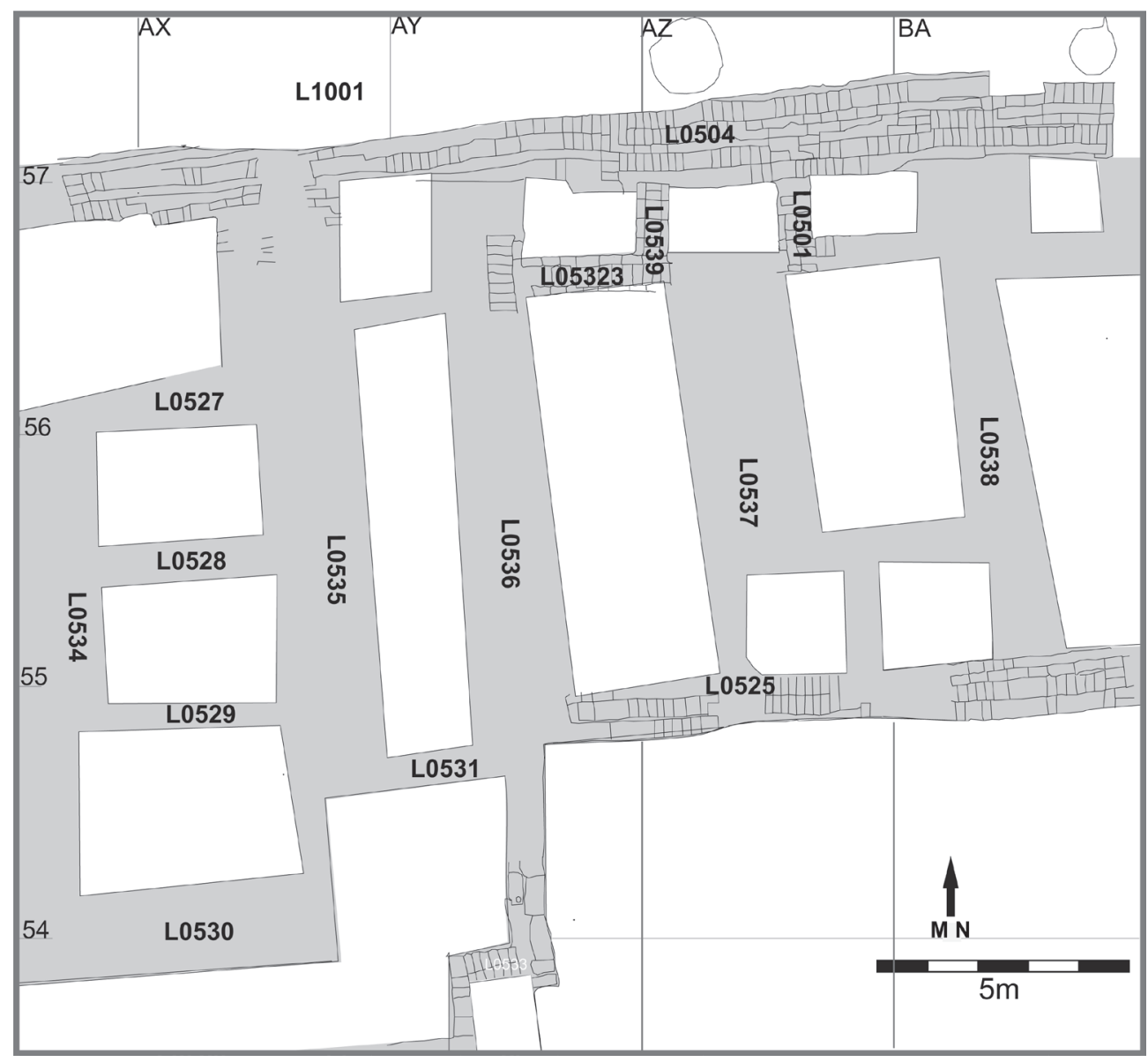

Figure 13. Reconstruction of Building F according to E. Crivelli Montero (2015: fig. 31).

foundations, which is all that remains) are up to $2.40 m$ thick, delimiting ten spaces of the cellular, "casemate" type ${ }^{43}$. Internal walls are generally thinner, from 2 to $1 \mathrm{~m}$ wide ${ }^{44}$.

\section{Building C}

Building C (L1008) is a solid but heavily denuded, quadrangular mudbrick construction, measuring $21 \times 22 \mathrm{~m}$ (fig. 15). It is oriented
NNE-SSW, as with many other structures at Tell el-Ghaba. Seven almost rectangular open spaces or casemates, asymmetrically disposed, were recognised ${ }^{45}$. The exterior walls of Building $\mathrm{C}$ are $2.9 \mathrm{~m}$ thick whereas the interior walls are about $1.7^{-1.8 m}$ wide. The thickness of the walls suggests the possibility of a multi-storeyed building. No foundations were found. The exploration carried out in the casemates did not unveil any defined occupation floors ${ }^{4}$.

43 Crivelli Montero, 2015: 79 .

44 Crivelli Montero, 2015: 79.

45 Crivelli Montero, 2015: 82-89.

46 Crivelli Montero, 2015: 84-89. 


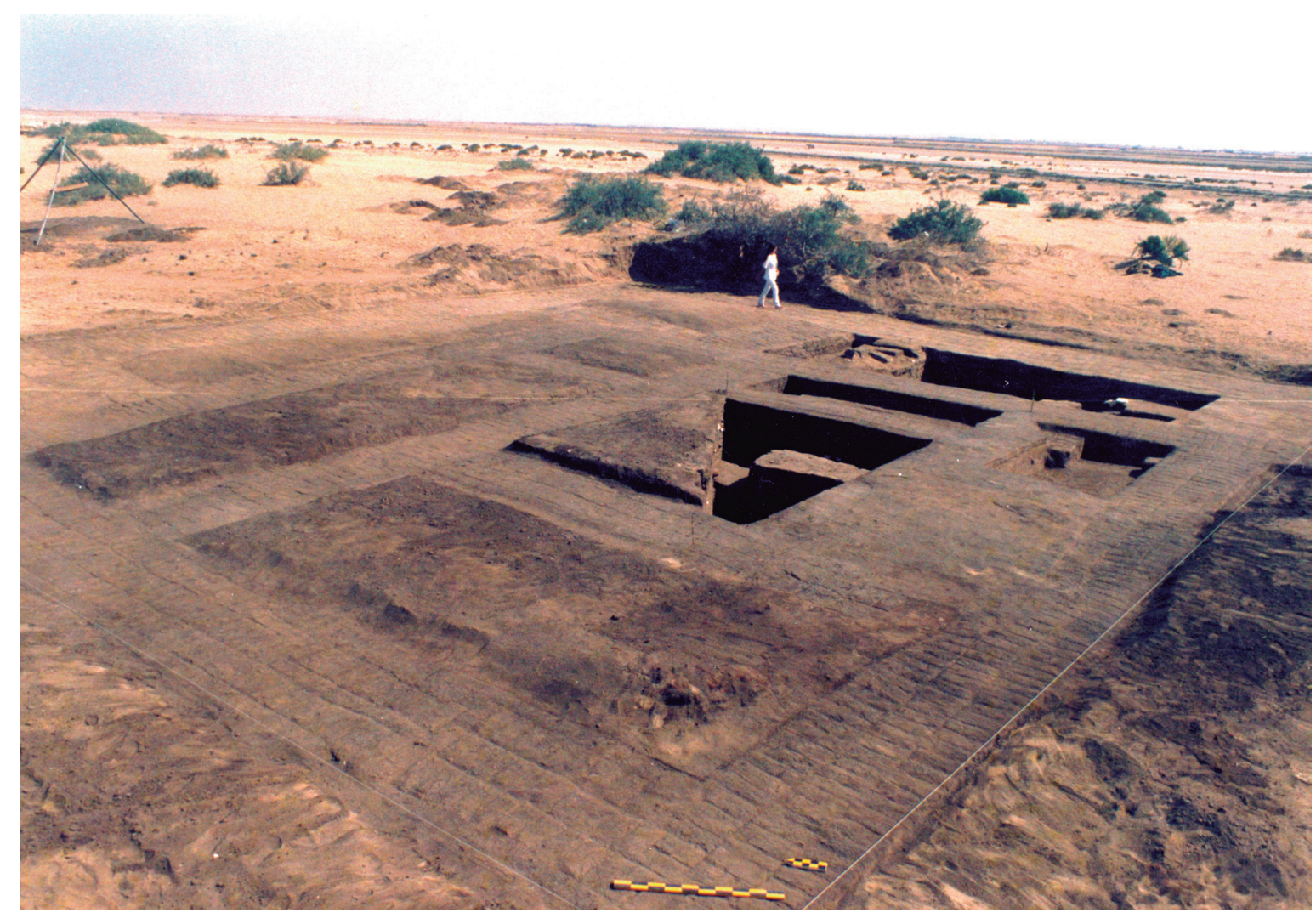

Figure 14. Building D.

The tower house, a peculiar kind of building, became common during the Third Intermediate-Late Periods, mainly (although not exclusively) in Lower Egypt. Marouard characterises it as a self-standing, many-storied, cellular private construction. It is square or slightly rectangular in layout, and no more than $25 \mathrm{~m}$ to the side. Mudbrick dimension of the tower houses are in good agreement with those of Building D and Building $\mathrm{C}^{47}$. The exterior walls are thicker than the inner ones, but always wider than $1 \mathrm{~m}$, since they were prepared to support the considerable weight of the upper stories. This means that the disposition of the spaces was approximately the same on each successive floor.

For Marouard, this kind of buildings was a response to the population pressure experimented in the Delta: it saved urban space and avoided encroaching cultivable land ${ }^{4}$. However, according to Herbich's survey, at Tell el-Ghaba there was still enough space along what was the preferential occupation area: the fringe of the lagoon, which meant fresh

47 Crivelli Montero, 2015: 79-81, 84 .

48 Marouard, 2014: 127-128. 
The Argentine Archaeological Mission at Tell el-Ghaba. A Third Intermediate-Early Saite Period Site... Silvia Lupo

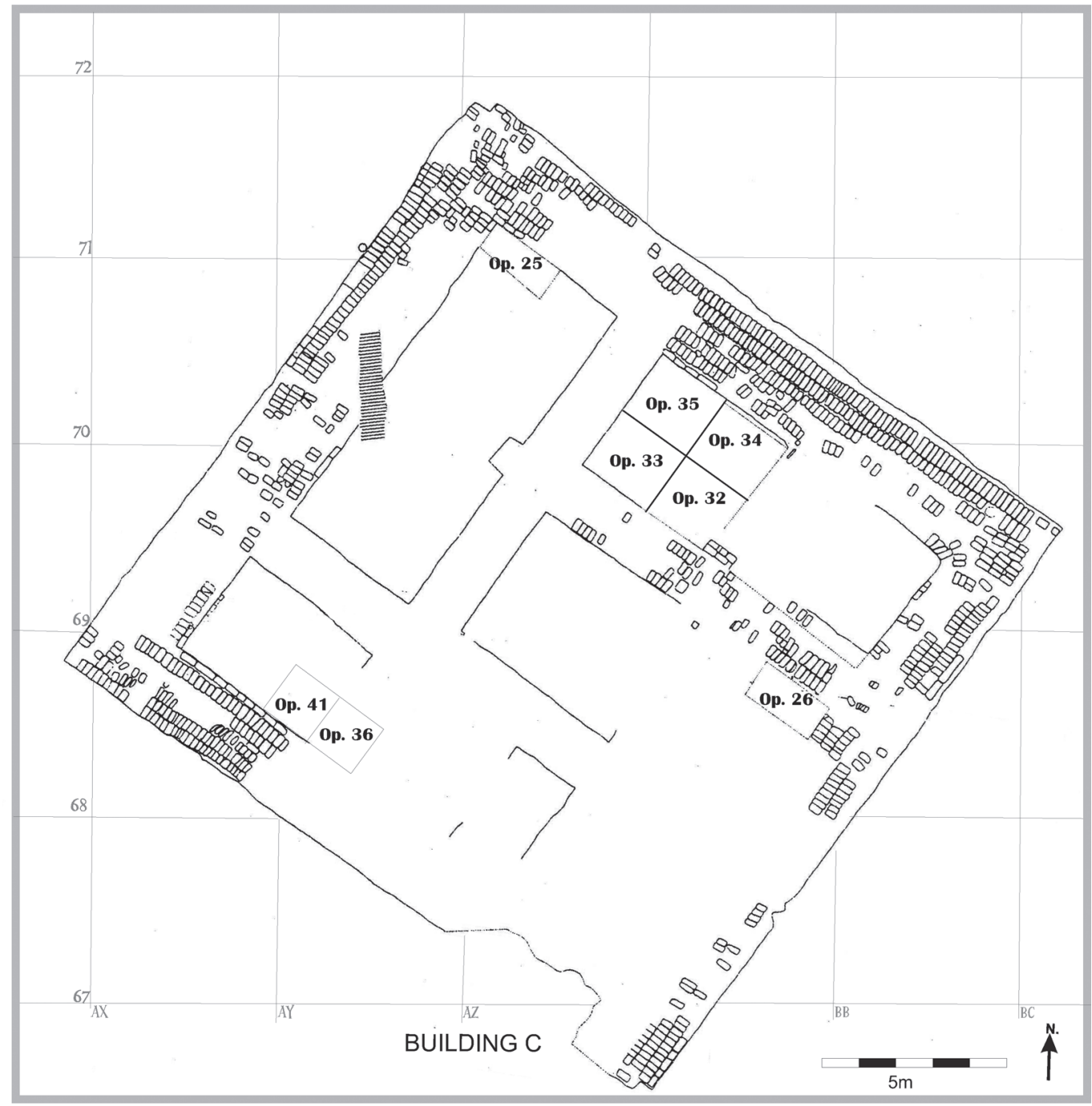

Figure 15. Building C

water and fish 49 . Other reasons may have been the exhibition of prestige (the height of the tower houses of modern Yemen depends on the status of the owners ${ }^{50}$ ), accompanied by a measure of security: only one front door for many rooms.
Considering that at Tell el-Ghaba only two cases of tower buildings have been excavated (Buildings $\mathrm{C}$ and $\mathrm{D}$ ) and that no floors were preserved, their function remains problematic ${ }^{1}$. Crivelli Montero suggests that the typology of this structure

49 Herbich, 2015: 105-116.

50 Marouard, 2014: figs 8 and 9 .

$5^{1}$ Crivelli Montero, 2015: 81. See also Crivelli Montero, 2015: 63-94, Lehmann, 2013; Hartung, Ballet, Effland, French, Hartmann, Herbich, Hoffmann, Hower-Tillmann, Kitagawa, Kopp, Kreibig, Lecuyot, Lösch, Marouard, Pithon and Zink, 2009: 83-19o among others. 
could be a simplification. As a matter of fact, the geophysical survey denoted several other structures ${ }^{52}$. Excavations at the site will be resumed as soon as the political situation in Egypt stabilises.

\section{2 | Chronology}

The dating of the site has been one of the main concerns of this project. In a site with no meaningful epigraphic inscriptions, pottery becomes an important chronological indicator ${ }^{53}$. There were two specific issues to be dealt with: the stratigraphic correlation among the excavated areas, and the temporal sequence of each area in particular.

\section{1 | Stratigraphic correlation among excavated} areas

The stratigraphic correlation could be established only among the occupation levels IV-VI of the adjacent Areas I and VIII. All other correlations were based on the study of the material, especially of the pottery. From the materials analysed and compared with those from other sites we may assume that: a) there is a chronological coincidence between Structure $\mathbf{M}$ and the underlying strata (Area II, Level I), and Building A and the underlying strata (Area I, Levels II-I), which would be associated with the beginning of the Third Intermediate Period, in the middle of the tenth century BC; b) there are coincidences and differences in the pottery types recovered from Buildings B (Area I, Level IV) and L (Area II, Level II). These two ceramic assemblages should be further analysed in relation to the architectural contexts in which they were found in order to determine whether their disparity is the consequence of their functional contexts or the result of a diachronic temporary use of the spaces at the site; c) some early Saite forms and imported pottery from the Eastern Mediterranean, dating to the late seventh century BC or beyond, only occur in the final destruction layer in Area I, but they do not occur in the same layer in Area II. This is probably because Area II was deserted before the conflagration episode took place 54 .

\section{2 | Temporal sequence of each area}

As for the temporal sequence of each area in particular, the evolution of the pottery types and the emergence of new types were our main chronological indicators.

The differences observed between the pottery types of the earlier occupation levels of Area I and those of the destruction layer have enabled us to tentatively date Tell el-Ghaba between the beginning of the Third Intermediate Period and the early Saite Period, coinciding with the middle of the tenth century $\mathrm{BC}$ and the late seventh century BC55. Tell el-Ghaba's types manufactured in Nile silt clay are similar to those

52 Crivelli Montero, personal communication.

53 Lupo, 2015: 139-308; Kohen, 2015: 309-326; Lupo and Kohen, 2015a: 327-340.

54 Lupo and Kohen, 2015a: 327-340.

55 Lupo, 2015: 139-308. 
found in the Third Intermediate Period and Saite contexts in Lower Egyptian sites such as Buto, Mit Rahineh, Tanis (structure elliptique), Tell Retaba in the wadi Tumilat and Hermopolis, as well as in Upper Egyptian sites as Herakleopolis Magna, Amarna, Gurna and others. According to studies carried out on the imported pottery by Kohen ${ }^{5}$, we may ascertain that this repertoire coincides with that attested in Syro-Palestinian sites, Philistia and Cyprus by the middle tenth/ninth-seventh centuries BC. The evidence suggests that, at least, by the beginning of the ninth century $\mathrm{BC}$, the site may have already had some degree of interaction with the trade network of the Eastern Mediterranean. In light of the amount and variety of imported material found in the final layer, these interactions must have increased significantly by the late seventh century BC.

\section{3 | Interactions}

It is possible that imports arrived at a port in the Delta and were then introduced into Tell el-Ghaba through the Pelusiac branch, or that they arrived by land through the South of Palestine ${ }^{57}$. During the late eighth-seventh centuries BC, the ports of Ashkelon and Ruqeish appear to have played a key role in a trade connection that combined sea and land routes. Ashkelon was a major Mediterranean port, and its economic expansion was closely tied to its participation in the Phoenician maritime trade ${ }^{8}$.

Likewise, Ruqeish appears to have been an intermediate stop for the vessels departing from Ashkelon and was, simultaneously, the starting point of the caravan route through Sinai. Ruqeish was apparently founded at the end of the eighth century BC by Sargon II, and appears to have functioned as a trading centre until sometime near the end of the Persian Period ${ }^{59}$. Regarding its location, an interaction of Tell el-Ghaba with the South of Palestine, through the caravan trade, appears plausible, especially if we consider that some of the imported ceramic types recovered at the site are also found at Ashdod, Tell es-Safi/Gath, Tell Batash/Timnah, Tell es-Zuweyid, Tell Jemmeh and at the Ruqeish cemetery $^{60}$.

\section{4 | Abandonment of Tell el-Ghaba}

Based on the evidence provided by the pottery recovered, we suggest two hypotheses in relation to the destruction event and the time period in which it took place: the Assyrian invasion on the one hand, and the Babylonian invasion on the other, as during the seventh century BC, these two great powers threatened the integrity of Egypt. When the Kushite kings took control of Egypt ${ }^{61}$, they adopted a more active policy towards the Levant and engaged in a war against the Assyrians who had seized Babylon and part

56 Kohen, 2015: 309-326.

57 Kohen, 2015: 309-326.

58 Master, 2003: 47.

59 Oren, Fleming, Kornberg, Feinstein and Nahshoni, 1986: 83-91.

6o Kohen, 2015: 309-326.

61 Twenty-fifth Dynasty, 747-656 BC (Myśliwiec, 1993: 220). 
of the eastern Mediterranean during the eighth century $\mathrm{BC}^{62}$.

In $701 \mathrm{BC}$, the Kushite King Shabitko (702-69o BC) led a campaign against Sennacherib (705-689 BC), in support of King Hezekiah of Judah, who had rebelled against the king of Assyria. Although the Egyptian army was defeated, the Kushite kings as well as the local governors of the Delta were determined to fight against the advance of the Assyrian army.

In response to this resolve, Esarhaddon (681-669 BC) invaded Egypt in 674 BC. Although his first attempt was repulsed, in $671 \mathrm{BC}$ he made a second attempt and captured the city of Memphis. Taharqa (69o664 BC) fled to Nubia and the Assyrian king imposed an oath on the local rulers of the Delta principalities to support the Assyrian rule. Necho I of Sais, father of Psametik I, was among these local rulers. Psametik I was taken to Niniveh to be instructed in the Assyrian customs. During his absence, Taharqa recovered the control of Egypt. In $667 \mathrm{BC}$, Esarhaddon's son, Asurbanipal (668-627 BC) invaded Egypt. Taharqa fled to Nubia and died in $66_{4} \mathrm{BC}$.

Psametik I (664-61o BC) returned from Niniveh and began to rule Egypt with the Assyrian support because his father, Necho I, had been loyal to the Assyrians. Psametik I and his successors intended to keep the eastern border free from foreign invaders. In view of the emergence of the Babylonian power, Egyptians and Assyrians allied, but this alliance lasted for a short period as in $655 \mathrm{BC}$ the Saite king shook off the Assyrian yoke.

A Babylonian invasion took place in 604 BC when Nebuchadnezzar (634-562 BC) de- stroyed the Philistine port of Ashkelon arriving in North Sinai in order to subdue Egypt.

Thus, we can infer that the destruction of Tell el-Ghaba occurred between the Egyptian military confrontation with Sennacherib in $701 \mathrm{BC}$ and the invasion of Nebuchadnezzar in 604 BC, after the death of Psametik I. It is hoped that further excavations will provide more definite answers.

\section{Bibliography}

'Abd el-Maksoud, M.

1992 "Project de sauvatage des sites antiques du Nord Sinaï", Discussion in Egyptology 24: 7-12.

Chauvin Grandela, A.

2010 "Tell el-Ghaba, Sinaí Norte: Campaña de Excavación 2010. Informe Preliminar", AntOr 8: 183-200.

2015 "Tell el-Ghaba, North Sinai. 2010 Excavation Season", in: S. Lupo (ed.): Tell el-Ghaba III. A Third Intermediate-Early Saite Period Site in the Egyptian Eastern Delta. Excavations 1995-1999 and 2010 in Areas I, II, VI and VIII, (BAR International Series 2756), Oxford: 95-104.

Crivelli Montero, E.

2005 "Stratigraphy", in: P. Fuscaldo, (ed.): Tell el-Ghaba I. A Saite Settlement in North Sinai, Egypt (Argentine Archaeological Mission 19952004). Vol I. The Catalogue (Colección Estudios 5), Buenos Aires: Part I, Area I: 50-51, 53-54, 84-86, 130-31, 144; Part II, Area II: 203-04, 221-03, 275-76, 279-80, 281-83, 303$344 ; 345-376$.

2015 "Excavations in Areas I, II and VI", in: S. Lupo (ed.): Tell el-Ghaba III. A Third Intermediate-Early Saite Period Site in the Egyptian Eastern Delta. Excavations 1995-1999 and 2010 in Areas I, II, VI and VIII, (BAR International Series 2756), Oxford: 63-94. 
The Argentine Archaeological Mission at Tell el-Ghaba. A Third Intermediate-Early Saite Period Site... Silvia Lupo

Crivelli Montero, E.; Kohen C.; Lupo S.

2012 "Two Foundation Deposits in a Domestic Context at Tell el-Ghaba, A First Millennium Settlement in the Eastern Delta, Egypt", fARCE 48: 205-220.

Glenn, A.; Goodfriend A.; Stanley, D.J.

1999 "Rapid strand-plain accretion in the northeastern Nile Delta in the $9^{\text {th }}$ century A.C. and the demise of the Port or Pelusium", Geology, v. 27, n 2: 147-150.

Hartung, U.; Ballet, P.; Effland, A.; French, P.; Hartmann, R.; Herbich, T.; Hoffmann, H.; Hower-Tilmann, E.; Kitagawa, C.; Kopp, P.; Kreibig, W.; Lecuyot, G.; Lösch, S.; MArouard, G.; Nerlich, A.; Pithon, M.; Zink, A. 2009 "Tell el-Fara'in-Buto. 10. Vorbericht", MDAIK 65: 83-19o.

Herbich, T.

2013 "Tell el-Ghaba, Geophysical survey 2010", PAM 22: 121-130.

2015 "Geophysical Prospection at Tell el-Ghaba", in: S. Lupo (ed.): Tell el-Ghaba III. A Third Intermediate-Early Saite Period Site in the Egyptian Eastern Delta. Excavations 19951999 and 2010 in Areas I, II, VI and VIII, (BAR International Series 2756), Oxford: 105-116.

Kohen, C.

2015 "Imported Pottery Types", in: S. Lupo (ed.): Tell el-Ghaba III. A Third Intermediate-Early Saite Period Site in the Egyptian Eastern Delta. Excavations 1995-1999 and 2010 in Areas I, II, VI and VIII, (BAR International Series 2756), Oxford: 309-326.

Lehmann, M.

2013 "Skylines, bridges and mud in the Delta and elsewhere. A comparison of Egyptian and Yemeni tower houses", MSA/EES Delta Survey Workshop March 22 ${ }^{\text {nd }}-23^{\text {rd }}$, British Council, Cairo. Online publication: http://ees.ac.uk/research/Delta_Workshop.html.

LuPo, S.

2015 "Egyptian Pottery Typology in Nile and Marl Clay", in: S. Lupo (ed.): Tell el-Ghaba III. A Third Intermediate-Early Saite Period Site in the Egyptian Eastern Delta. Excavations 19951999 and 2010 in Areas I, II, VI and VIII, (BAR International Series 2756), Oxford: 139-308.

Lupo, S.; Cremonte, M.B.

2013 "Local Vessels and Imported Copies Manufactured in Sandy Fabrics at Tell el-Ghaba, North Sinai", fEA 99: 191- 216.

Lupo, S.; Crivelli Montero, E.; Kohen, C.

In press "Building $\mathrm{B}$, a domestic construction at Tell el-Ghaba, North Sinai", in Proceedings of the XI International Congress of Egyptologists, Florence, August 2015.

Lupo, S.; Kohen, C.

2015a "Ceramic Typology and Chronology. An Assessment of Tell el-Ghaba's Dating", in: S. Lupo (ed.): Tell el-Ghaba III. A Third Intermediate-Early Saite Period Site in the Egyptian Eastern Delta. Excavations 1995-1999 and 2010 in Areas I, II, VI and VIII, (BAR International Series 2756), Oxford: 327-340.

2015b "Early Occupation of Area I at Tell el-Ghaba, North Sinai", BCE 25: 199-235.

Marchand, S.

2004 "Histoire paralèlle. La céramique et les dépôts de fondation de l'Égypte ancienne", Égypte, Afrique \& Orient 36: 7-20.

Marouard, G.

2014 "Maisons-tours et organisation des quartiers domestiques sans les agglomerations du Delta: l'example de Bouto de la Basse Époque aux premiers Laguides", in: S. Marchi (ed.): Les maisons-tours en Égypte durant la Basse-Époque, les périods Ptólemaïque et Romaine. Actes de la table-ronde de Paris. Université Paris-Sorbonne (Paris IV), 29-30 Novembre 2012, NeHeT Revue numérique d'Égyptologie 2: 105-133.

\section{Master, D.M.}

2003 "Trade and Politics: Ashkelon's Balancing Act in the Seventh Century B.C.E.", BASOR 330: 47-69.

Myśliwiec, K.

1993 The Twilight of Ancient Egypt. First Millennium B.C.E. Ithaca, London. 
Oren, E.; Fleming, E.N.; Kornberg, S.; FeinStein, I.; NAhshoni, P.

1986 "A Phoenician Emporium on the Border of Egypt", Qadmoniot. Quarterly for the Antiquities of Eretz-Israel and Bible Lands 19, 3-4: 83-91.

TAYLOR, J.H.

2000 "The Third Intermediate Period (1069-664 BC)", in: I. Shaw (ed.): The Oxford History of Ancient Egypt, Oxford: 358-59.

Tell el-Ghaba geophysical survey, 2010: http:// www.pcma.uw.edu.pl/en/pcma-newsletter/2010/.

Valbelle, D.; le Saout, F.; Chartier-RayMOND, M.; 'AbD El-Samie, M.; Traunegker, Cl.; Wagner, G.; Carrez-Maratray, J.; ZigNANI, P.

1992 "Reconaissance archéologique à la pointe orientale du Delta. Rapport préliminaire sur les saisons 1990 et 1991", CRIPEL 14: 11-22.

Weinstein, J.M.

1973 Foundation Deposits in Ancient Egypt: a Dissertation in Oriental Studies. Ann Arbor. 


\section{Trabajos de Egiptología}

Papers on Ancient Egypt 


\section{Consejo editorial}

\section{Director}

Miguel Ángel Molinero Polo

Universidad de La Laguna, Tenerife, Islas Canarias

\section{Secretaría de edición}

Lucía Díaz-Iglesias Llanos

Centro Superior de Investigaciones Científicas, Madrid

Alba María Villar Gómez

Universidad Autónoma de Madrid

\section{Colaborador de edición / English editorial assistant}

Kenneth Griffin

Swansea University, Gales, Reino Unido

\section{Consejo de redacción}

Antonio Pérez Largacha

Universidad de Castilla - La Mancha

José Ramón Pérez-Accino Picatoste

Universidad Complutense de Madrid

$\mathrm{M}^{\mathrm{a}}$ Covadonga Sevilla Cueva

Universidad Autónoma de Madrid

\section{Comité científico}

Josep Cervelló Autuori

Universitat Autònoma de Barcelona

María José López-Grande

Universidad Autónoma de Madrid

Josep Padró i Parcerisa

Universitat de Barcelona

M. ${ }^{a}$ Carmen Pérez Die

Museo Arqueológico Nacional, Madrid

Esther Pons Mellado

Museo Arqueológico Nacional, Madrid

José Miguel Serrano Delgado

Universidad de Sevilla 


\section{Trabajos de Egiptología}

Papers on Ancient Egypt

Número 7

2016 
Trabajos de Egiptología está producida por

Isfet. Egiptología e Historia

con la colaboración del Centro de Estudios Africanos

de la Universidad de La Laguna

C/ Blanco 1, $2^{\circ}$

38400 Puerto de la Cruz

Tenerife-Islas Canarias

España

(C) De los textos: sus autores y Trabajos de Egiptología

Diseño de arte y maquetación

Marian Montesdeoca y Ulises Ramos

info@marianmontesdeoca.com

Imprime: Gráfica Los Majuelos

Depósito Legal: TF 935-2015

ISSN: 1695-4750 


\section{Contents}

$\begin{array}{ll}\text { Prefacio/Foreword } & 7\end{array}$

Chiefs, Kings, and Patrons. Leadership and Social Logics in the Beginnings of Ancient Egypt 9 Marcelo CAMPAGNO

The Development of Local Osirian Forms. An Explanatory Model

Lucía DÍAZ-IGLESIAS LLANOS

Shaushka, the Traveling Goddess

Graciela GESTOSO SINGER

What are we Talking about when we Talk about Memphis?

Maria Helena Trindade LOPES

Stone Vessels of Egyptian Appearance from Ibiza

67

María José LÓPEZ-GRANDE

The Argentine Archaeological Mission at Tell el-Ghaba. A Third Intermediate-Early Saite Period Site on the Ancient Egyptian Eastern Border. Remarks and Main Results Silvia LUPO

TT 209. Objectives of the proyecto dos cero nueve and the Name of the Tomb Owner Miguel Ángel MOLINERO POLO

The Herakleopolis Magna Project (Ehnasya el Medina). Summary and Results of Work 2000-2015

M. ${ }^{a}$ Carmen PÉREZ DIE

Tombs of the Roman Period in Sector 26 of the High Necropolis Archaeological Site of Oxyrhynchus, El-Bahnasa

Esther PONS MELLADO

The Decoration of the Pronaos of Petosiris' Tomb. Themes, Scenes, Styles and Techniques José das Candeias SALES

The Artist in his Context: New Tendencies on the Research of Ancient Egyptian Art Inmaculada VIVAS SÁINZ 